УДК 619:351.765+351.779:341.232.4:343.58

(C) 2017

Свстаф'єва В. О., доктор ветеринарних наук, професор,

Кручиненко О. В., кандидат ветеринарних наук,

Клименко О. С., кандидат ветеринарних наук,

Мельничук В. В., кандидат ветеринарних наук

Полтавська державна аграрна академія

\title{
ЮРИДИЧНІ АСПЕКТИ ЩОДО АДАПТАЦІЇ УКРАЇНСЬКОГО ЗАКОНОДАВСТВА ДО ВИМОГ ЄВРОПЕЙСЬКОГО СОЮЗУ 3 ПИТАНЬ ЖОРСТОКОГО ПОВОДЖЕННЯ 3 ТВАРИНАМИ
}

\section{Рецензент - доктор ветеринарних наук, професор Б. П. Киричко}

\begin{abstract}
Наведені результати аналізу сучасного стану міжнародних нормативно-правових актів та українського законодавства стосовно захисту тварин, підстав і видів юридичної відповідальності за вчинення жорстокого поводження з тваринами, а також принципів етичного ставлення до тварин, особливо фахівців з біології, ветеринарії, медицини. Подаються відомості стосовно реалізації та дотримання етико-правових норм вимог біоетики під час проведення експериментів, наукових досліджень на тваринах, зокрема у ветеринаріі.
\end{abstract}

Ключові слова: біоетика, жорстоке поводження з тваринами, кримінальна відповідальність, законодавство Украӥни.

Постановка проблеми. Тваринний світ є одним із компонентів навколишнього природного середовища, національним багатством України, джерелом духовного та естетичного збагачення і виховання людей, об'єктом наукових досліджень, а також важливою базою для одержання промислової і лікарської сировини, харчових продуктів та інших матеріальних цінностей [1].

Як випливає зі змісту численних міжнародних нормативно-правових актів у сфері захисту тварин, кожна людина має моральний обов'язок поважати всіх живих істот нашої планети, зокрема й тварин, ураховуючи при цьому ту важливу обставину, що останні, як і люди, здатні відчувати біль, страждати та пам'ятати [4]. Ще за радянських часів О. М. Ігнатов звертав увагу на те, що безглузде знищення тварин, їх катування i тортури не тільки ображають моральні почуття громадян, а й відбуваючись на очах дітей, розвивають у них такі негативні риси, як жорстокість $\mathrm{i}$ душевна черствість, байдужість до страждань живої істоти, сприяють формуванню садистських нахилів, тобто завдають величезної шкоди їх вихованню [5].

Сучасне реформування освіти вимагає разом 3 перебудовою навчально-виховного процесу докорінної зміни педагогічного менталітету, засво- єння педагогами біоетичних принципів, без яких неможлива реалізація одного з важливих пріоритетів державної політики в галузі освіти - створення безпечних для здоров'я та сприятливих для гармонійного фізичного, нервово-психічного й інтелектуального розвитку молодого покоління України умов навчання і виховання. Найважливіша причина виділення біоетики в самостійну дисципліну і формування біоетичної проблематики - це нове розуміння взаємовідносин між людиною і твариною. Реалізація вимог біоетики та біобезпеки, які формуються сьогодні, буде здійснюватися майбутніми спеціалістами. Адже саме їм уже завтра доведеться проводити наукові та науково-технічні розробки - створювати нові технології на клітинному та молекулярному рівнях, розробляти та реалізовувати технології промислового випуску [6].

Аналіз основних досліджень і публікацій, у яких започатковано розв'язання проблеми. Піфагор - грецький філософ і математик, - один 3 перших відомих представників Стародавнього світу, висував питання необхідності поваги до тварин і небажаності жорстокого поводження 3 ними. Відомий італійський живописець Леонардо да Вінчі, як зазначають сучасники, любив тварин і вважав, що мораль по відношенню до тварин повинна розвиватися у сторону недопустимості жорстокості щодо них. Також особливо негативно він відносився до людей, які знущалися над тваринами з хуліганських мотивів, і зазначав, що прийде час, коли суспільство буде дивитися на «вбивцю» тварини так, як воно дивиться на вбивцю людини.

Перший у світі Закон про захист тварин під назвою «Акт про попередження жорстокого й негідного поводження 3 худобою» було прийнято 1822 року у Великій Британії. Зусиллями члена британського парламенту Річарда Мартіна та лорда-канцлера Томаса Ерскіна вперше в історії людства коні та інші сільськогосподарські тва- 


\section{ВЕТЕРИНАРНА МЕДИЦИНА}

рини отримали законодавчий захист від страждання.

У суспільстві забезпечено гуманне поводження зі свійськими та дикими непродуктивними й продуктивними тваринами, тобто дії, спрямовані на забезпечення тваринам умов, які відповідають їхнім фізіологічним, біологічним і видовим особливостям, створення можливостей для їх існування й уважного ставлення до стану здоров'я тварин [3]. Тому чинне законодавство, у тому числі й кримінальне, має регулювати, передусім, ті відносини, які складаються у сфері охорони тварин, що перебувають у певному біологічному стані, у якому вони здатні до самопідтримання, самовідтворення та саморозвитку, а також для яких характерна чутливість до подразнень та рухливість, можливість обміну із зовнішнім світом. Так, Закон України «Про тваринний світ» від 13 грудня 2001 р. одним зі своїх завдань має забезпечити умови постійного існування тварин, передбачаючи захист (охорону) їх життя на всіх стадіях розвитку. У преамбулі цього Закону тварини розглянуті як компонент навколишнього природного середовища. Тому важливе значення має усвідомлення та знання сучасного стану міжнародних i вітчизняних нормативноправових актів стосовно захисту тварин, підстав і видів юридичної відповідальності за вчинення жорстокого поводження 3 тваринами, а також етико-правових норм біоетики та біобезпеки під час проведення експериментів над тваринами.

Метою досліджень було проаналізувати сучасний стан міжнародних нормативно-правових актів українського законодавства стосовно захисту тварин та їх адаптацію до Свропейського союзу з питань жорстокого поводження 3 тваринами.

Результати досліджень. На початку нового тисячоліття приходить новий світогляд, у якому людина є істотою у грандіозному ланцюгу інших істот, кожна 3 яких має автономну цінність безвідносно до їі користі для людини. Людство уже давно підтвердило своє бажання захистити тваринний світ від протиправних посягань. Так, у ФНР права тварин гарантовано Конституцією держави, зокрема статтею, якою державу зобов'язано поважати честь і гідність не лише людини, а й тварини. У Швейцарській Конфедерації 3 2008 року діє закон про права тварин, який детально регламентує поводження 3 дикими і домашніми тваринами. Однією 3 причин прийняття такого закону стала зміна поглядів швейцарців на ставлення до безпритульних тварин, яке розглядається європейською спільнотою як глобальна екоетична проблема - проблема безправ'я природи. Ціль законів, прийнятих стосовно охорони довкілля, захисту тварин, - зменшити страждання живого [7].

Міжнародне співтовариство уже давно заявило про своє бажання захистити тваринний світ від протиправних посягань, що підтверджується прийняттям міжнародно-правових актів, таких як: Свропейська конвенція про захист тварин під час міжнародних перевезень (1968 р.) [8], Конвенція про міжнародну торгівлю видами дикої флори i фауни, що перебувають під загрозою зникнення (1973р.), Всесвітня Декларація прав тварин (1978 р.) [9], Свропейська конвенція про захист хребетних тварин, що використовуються для дослідних та інших наукових цілей (1986 р.) [10], Європейська конвенція щодо захисту домашніх тварин (1987 р.) [11] тощо. Крім того, у більшості зарубіжних держав створено інститут захисту прав тварин, функціонують громадські організації та спеціалізовані відомства щодо захисту тварин.

Водночас, Україна є лідером у рейтингу серед країн, яким притаманне явище прояву жорстокості у поводжені з тваринами. На сьогодні правові засади унеможливлення жорстокого поводження 3 тваринами визначені Законами України, а саме: «Про захист тварин від жорстокого поводження», «Про тваринний світ», «Про охорону навколишнього природного середовища», «Про ветеринарну медицину», «Про забезпечення санітарного та епідемічного благополуччя населення», «Про захист населення від інфекційних хвороб» та іншими нормативно-правовими актами. Так, Закон України «Про захист тварин від жорстокого поводження», а саме ст. 6 визначає виховання гуманного ставлення до тварин важливою складовою етичного, культурного та екологічного виховання громадян, яке передбачає формування високого рівня еколого-етичної свідомості та культури громадян. Відповідно до законодавства, таке виховання забезпечується шляхом викладання курсів з екологічної етики та гуманного ставлення до тварин у дошкільних навчальних закладах, у системі загальної середньої, професійно-технічної та вищої освіти [12].

Згідно з міжнародним правом, норми щодо захисту тварин поділяються на три категорії. Перший - це захист тварин (видів), яким загрожує вимирання (Міжнародна конвенція про регулювання китобійного промислу 1946 р., Конвенція ЮНЕСКО про охорону всесвітньої культурної і природної спадщини 1972 р., Конвенція про охорону тюленів Антарктики 1973 р., Угода про збереження білих ведмедів 1973 р., Конвенція про міжнародну торгівлю видами дикої фауни i 


\section{ВЕТЕРИНАРНА МЕДИЦИНА}

флори, які перебувають під загрозою зникнення 1973 р., Конвенція про охорону біологічної різноманітності 1992 р. та ін.). Другий - захист диких видів тварин (Міжнародна конвенція про охорону птахів 1950 р., Конвенція про охорону дикої флори і фауни та природних середовищ існування в Європі 1979 р., Боннська конвенція про охорону мігруючих видів диких тварин 1979 р., Конвенція про збереження морських живих ресурсів Антарктики 1980 р. та ін.). Третій - захист домашніх тварин (Свропейська конвенція про захист домашніх тварин 1992 р.) [13].

Кримінальний закон України передбачає кримінальну відповідальність за знущання над тваринами, що відносяться до хребетних, вчинене із застосуванням жорстоких методів або з хуліганських мотивів, а також нацькування зазначених тварин одна на одну, вчинене 3 хуліганських чи корисливих мотивів (ст. 299 чинного КК України «Жорстоке поводження 3 тваринами»). За порушення вимог законодавства у сфері захисту тварин від жорстокого поводження із ними винні особи несуть не лише адміністративну (ст. 89 КпАП України) та цивільноправову, а й кримінальну відповідальність (ст. 299 КК України).

Проглядаються шляхи адаптації Українського законодавства до Європейського союзу з питань жорстокого поводження $з$ тваринами. Так, Україна приєдналася до Конвенції про збереження мігруючих видів диких тварин від 23 червня 1979 р. шляхом прийняття 19 березня 1999 р. Закону України «Про приєднання України до Конвенції про збереження мігруючих видів»; Конвенції про охорону дикої флори та фауни i природних середовищ існування в Свропі від 19 вересня 1979 р. Українська держава приєдналася 29 жовтня 1996 р. шляхом прийняття Закону України «Про приєднання України до Конвенції 1979 р. про охорону дикої флори та фауни і природних середовищ існування в Свропі» [13].

До світоглядних засад, які базуються на основоположних загальнолюдських цінностях, таких як гуманізм, любов до всіх виявів життя, визнання життя найвищою цінністю, зокрема тваринного світу, відноситься й таке поняття як «біоетика». Воно ввійшло в науковий обіг, набуло значного поширення й глибокого теоретичного опрацювання. Актуальність біоетичної проблематики, усвідомлення іiі важливості демонструє той факт, що світова громадськість в особі ЮНЕСКО зробила етику в галузі науки і технологій одним із пріоритетів своєї стратегії на 2002-2007 роки. Тому вирішення питання щодо біоетичних принципів активно проводиться i в українському суспільстві [14].
Має право на існування новий термін - ветеринарна біоетика - принципи етичного ставлення до тварин ветеринарного фахівця. Система підготовки ветеринарних фахівців за кордоном давно спрямована на випуск спеціалістів, для яких насамперед важливим є надання допомоги тварині. У аграрних ВНЗ України підготовка лікарів 3 ветеринарної медицини повинна допомогти майбутнім спеціалістам орієнтуватися в їх роботі на потреби тварини, бачити в них істот, що мають самостійну цінність, а не просто знаряддя задоволення потреб людини. У центрі його уваги має залишатися тварина. Хоча ставлення людства в цілому до тварин багато в чому не відповідає принципам етики та біоетики, кожен внесок у зміцнення біоетичних поглядів наближає час їх повної перемоги $[15,16]$.

Чим більше наука прагне до того, щоб слугувати інтересам та благу людства, тим більше вона набуває вигляду певної технології, в якій значну роль починають відігравати експерименти над тваринами [6]. Тому важливим кроком на шляху гуманізації експериментів над тваринами було підписання Президентом України Закону № 3447-IV «Про захист тварин від жорстокого поводження», де згідно зі ст. 26 цього Закону «Правила поводження 3 тваринами, що використовуються в наукових експериментах, тестуванні, навчальному процесі, виробництві біологічних препаратів», всі експерименти 3 використанням тварин повинні проводитися з урахуванням біоетичних принципів та проходити попередню етичну експертизу. Біоетична (етична) експертиза наукових досліджень сприяє втіленню в науковий проект (теорію, методологію, практику) біоетичних цінностей та принципів. Вона спрямована на забезпечення захисту прав людини, тварин та суб'єктів природи, які беруть участь у дослідженні, збереження їх здоров'я та благополуччя, життя та еволюційний розвиток.

У 2005 році дотримання етико-правових норм та вимог під час проведення наукових досліджень стає необхідною і важливою складовою атестації наукових і науково-педагогічних працівників в Україні. 31 березня 2005 року Вища атестаційна комісія України видає Наказ «Про внесення доповнень до переліків і форм документів, що використовуються при атестації наукових і науково-педагогічних працівників», згідно 3 яким, до переліку документів, які подаються до спеціалізованої вченої ради та ВАК України здобувачем наукового ступеня з медичних, біологічних і ветеринарних наук, має бути доданий висновок комітету 3 етики щодо проведення біоетичної експертизи дисертаційного дослідження. 


\section{ВЕТЕРИНАРНА МЕДИЦИНА}

Висновок. Отже, Європейська конвенція про захист домашніх тварин 1987 р. $є$ базовим документом, що визначає європейські стандарти щодо благополуччя домашніх тварин та їхнього захисту від жорстокого поводження і яка ратифікована Україною. Із прийняттям Закону України «Про захист тварин від жорстокого поводження» можна стверджувати про формування в Україні остаточного правового інституту біоетичного поводження 3 тваринами та його базового принципу - наявності у тварин природних прав. Разом 3 тим, $з$ метою адаптації українського за-

\section{БІБЛІОГРАФІЯ}

1. Вереша Р. В. Кримінальна відповідальність за жорстоке поводження 3 тваринами (порівняльноправовий аспект) / Р. В. Вереша // Вісник Академії адвокатури України. - 2014. - Т. 11, №1 (29). C. 53-61.

2. Закон України «Про захист тварин від жорстокого поводження» від 21.02.2006 р. // Відомості Верховної Ради. - 2006. - №27. - Ст. 230.

3. Закон України «Про тваринний світ» від 13 грудня 2001 р. // Відомості Верховної Ради. 2002. - №14. - Ст. 97.

4. Калмиков Д. О. Санкції статті Кримінального кодексу України сучасний стан і перспективи вдосконалення / Д. О. Калмиков // Форум права. - 2013. - №2. - С. 205-215.

5. Курс советского уголовного права: в 6 т., Т. 4 / [Пионтковский А. А., Ромашкин П. С., Кригер Г. А. и др.]. - М. : изд-во «Наука», 1971. - 343 с.

6. Почернясва В. Ф. Біоетика експериментальні та клінічні дослідження : [навчальний посібник для ВНЗ медичного та біологічного напрямку] / В. Ф. Почерняєва, С. В. Денисенко, С. Б. Передера. - Полтава : «ПП Шевченко Р. В.», 2010. - 164 с.

7. Щорічна доповідь уповноваженого Верховної Ради України з прав людини про стан дотримання та захисту прав і свобод людини в Україні. Омбудсман України 2011 р. - С. 179 [Електронний ресурс]. - Режим доступу : URL : risu.org.ua/php_uploads/files/articles/ArticleFiles_4 6828 plugin-Dopovid 8 1.pdf.

8. Європейська конвенція про захист тварин під час міжнародних перевезень від 13 грудня 1968 р. [Електронний ресурс]. - Режим доступу : http://zakon.nau.ua/doc/?uid=1014.5643.0.

9. Всесвітня Декларація прав тварин від 23 вересня 1977 р. [Електронний ресурс]. - Режим доступу : http://www.shelteranimals.kiev.ua/ index.php $/ \% \mathrm{D} 0 \% 9 \mathrm{C} \% \mathrm{D} 1 \% 96 \% \mathrm{D} 0 \% \mathrm{~B} 6 \% \mathrm{D} 0 \% \mathrm{BD} \% \mathrm{D}$ $0 \% \mathrm{~B} 0 \% \quad \mathrm{D} 1 \% 80 \% \mathrm{D} 0 \% \mathrm{BE} \% \mathrm{D} 0 \% \mathrm{~B} 4 \% \mathrm{D} 0 \% \mathrm{BD} \%$ D0\%B8\%D0\%B9\%D0\%B4\%D0\%BE\%D1\%81\%D0 конодавства до європейського стосовно захисту тварин, всі експерименти з використанням тварин, які виконуються на базах наукових, науково-дослідних та навчальних установ України, повинні проводитися 3 урахуванням біоетичних принципів та проходити попередню етичну експертизу, що буде унеможливлювати жорстоке поводження 3 тваринами.

Перспективами подальших досліджень планується проведення досліджень щодо створення комісії з біоетики на базі Полтавської державної аграрної академії.

$\% \mathrm{~B} 2 \% \mathrm{D} 1 \% 96 \% \mathrm{D} 0 \% \mathrm{~B} 4 /$ vsemirnaya-deklaraciyapravzhivotnyh.html.

10. Свропейська конвенція щодо захисту хребетних тварин, що використовуються для дослідних та інших наукових цілей від 18 березня 1986 р. [Електронний ресурс]. - Режим доступу : http://zakon2.rada.gov.ua/ laws/show/994_137.

11. Свропейська конвенція про захист домашніх тварин від 13 лютого 1987 р. [Електронний ресурс]. - Режим доступу : http://zakon.nau.ua/doc/ ?code $=994$ a15.

12. Про ветеринарну медицину : Закон України від 25.06.1992 р. за № 2498-ХІІ // Відомості Верховної Ради України. - 1992. - №36 (08.09.92). Ст. 531.

13. Турська В. О. $\quad$ http://194.44.11.130/cgibin/irbis nbuv/cgiirbis 64.exe?Z21 ID $=\& I 21 D B N=$ $\mathrm{EC} \& \mathrm{P} 21 \mathrm{DBN}=\mathrm{EC} \& \mathrm{R} 21 \mathrm{DBN}=1 \& \mathrm{R} 21 \mathrm{DBN}=2 \& \mathrm{~S} 2$ $1 \mathrm{STN}=1 \& \mathrm{~S} 21 \mathrm{REF}=10 \& \mathrm{~S} 21 \mathrm{FMT}=$ fullwebr $\& \mathrm{C} 21 \mathrm{C}$ $\mathrm{OM}=\mathrm{S} \& \mathrm{~S} 21 \mathrm{CNR}=20 \& \mathrm{~S} 21 \mathrm{P} 01=0 \& \mathrm{~S} 21 \mathrm{P} 02=0 \& \mathrm{~S} 21$ $\mathrm{P} 03=\mathrm{M}=\& \mathrm{~S} 21 \mathrm{COLORTERMS}=0 \& \mathrm{~S} 21 \mathrm{STR}=$ Адмін істративно-правове регулювання захисту тварин від жорстокого поводження : автореф. дис. ... к. ю. н. : 12.00.07 / Віта Олегівна Турська. - Одеса, 2016. $-232 \mathrm{c}$.

14. Кисельов М. Філософські та світоглядні аспекти біологічної етики / М. Кисельов // Bicник Національної академії наук України. - 2001. - №11. - C. 16-25.

15. Демченко В. К. Міжнародні юридичні аспекти біоетики / Антологія біоетики; за ред. Ю. І. Кундієва. - Львів: БаК, 2003. - С. 87-90.

16. International Association Against Painful Experiments on Animals - URL : http: // www.iaapea.com/mag.4.1.html. IAAPEA Magazine/ IAAPEA award seven humane research grants in Ukraine // Spring 2004 [Електронний ресурс]. - Режим доступу : http://www.km.ru/referats/317901BD2C734 F04B A24B6C BAD0422B4. 